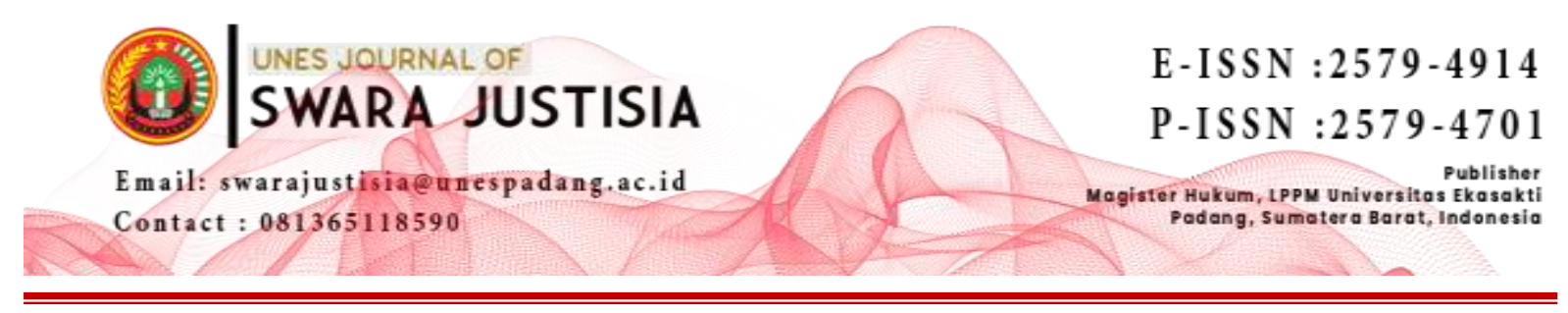

\title{
OPTIMALISASI PERAN UNIT IDENTIFIKASI FORENSIK SATRESKRIM POLRESTA PADANG DALAM PENYIDIKAN TINDAK PIDANA PEMBUNUHAN
}

\author{
Reza Marthadinata Putra \\ Program Magister Ilmu Hukum,Universitas Ekasakti, Padang \\ Email: rezamarthadinataputra@gmail.com
}

\begin{abstract}
The results of the activities of the Identification Unit are the capital in the disclosure of criminal acts. In investigating a murder case, the Police in addition to looking for traces of the suspect also focus on investigating the victim, in the hope that if the identity of the victim can be known, the investigation can be carried out more directed because in general there is a relationship between the perpetrator and the victim so that investigators can more easily make decisions. a list of people who can be suspected of being criminals. Constraints on the Role of the Forensic Identification Unit in the Investigation of the Crime of Murder at LP 310/A/VIII/2020/Sector and LP 128-B/V/2020/LUBEG is a factor in the ability of officers to identify, process processing at the scene of the incident not being thorough, ignoring or ignore any signs, objects, traces and so on. Lack of legal awareness and public concern. Optimizing the Role of the Forensic Identification Unit at the Padang Police Criminal Investigation Unit in the Investigation of the Crime of Murder is to propose in stages to include identification unit personnel in special education in the field of criminal identification.
\end{abstract}

Keywords: Optimization, Forensic Identification Unit, Investigation, Murder crime

\begin{abstract}
ABSTRAK
Hasil kegiatan Unit Identifikasi merupakan modal dalam pengungkapan tindak pidana. Dalam pengusutan kasus pembunuhan, Pihak Kepolisian selain mencari jejak tersangka juga memfokuskan penyidikan kepada Korban hal ini dengan harapan jika jati diri korban dapat diketahui maka pelaksanaan penyidikan dapat dilakukan dengan lebih terarah oleh karena pada umumnya ada hubungan antara pelaku dan korbannya sehingga penyidik dapat lebih mudah membuat daftar orang-orang yang dapat dicurigai sebagai pelaku tindak pidana. Kendala Peran Unit Identifikasi Forensik Dalam Penyidikan Tindak Pidana Pembunuhan Pada LP 310/A/VIII/2020/Sektor Dan LP 128-B/V/2020/LUBEG adalah faktor Kemampuan petugas dalam melakukan identifikasi, proses pengolahan pada tempat kejadian kurang teliti, mengabaikan ataupun menghiraukan sesuatu tandatanda, benda benda, jejak-jejak dan sebagainya. Kurangnya kesadaran hukum dan kepedulian masyarakat. Optimalisasi Peran Unit Identifikasi Forensik Pada Satreskrim Polresta Padang Dalam Penyidikan Tindak Pidana Pembunuhan adalah mengusulkan secara berjenjang untuk mengikutsertakan personel unit identifikasi pada pendidikan khusus bidang identifikasi tindak pidana.
\end{abstract}


Kata Kunci: Optimasi, Unit Identifikasi Forensik, Investigasi, Kejahatan pembunuhan

\section{PENDAHULUAN}

Penegakan hukum di dalam sistem peradilan pidana bertujuan untuk menanggulagi setiap kejahatan. Bahwa yang dimaksud sistem peradilan pidana ialah suatu sistem berprosesnya suatu peradilan pidana, dimana masing-masing komponen fungsi yang terdiri dari kepolisian sebagai penyidik, kejaksaan sebagai penuntut umum, pengadilan sebagai pihak yang mengadili dan lembaga pemasyarakatan yang berfungsi untuk memasyarakatkan kembali para terhukum, yang bekerja secara bersama sama, terpadu dalam usaha untuk mencapai tujuan bersama yaitu untuk menanggulangi kejahatan. ${ }^{1}$

Scientific Crime Investigation yaitu proses penyidikan yang dalam sistem pembuktiannya memanfaatkan ilmu pengetahuan dan teknologi atau memanfaatkan fungsi forensik (Identifikasi Forensik, Laboratorium Forensik, Psikologi Forensik, Kedokteran Forensik dan ahli forensik lainnya). Pembuktian secara ilmiah pada proses penyidikan kasus pidana akan merupakan alat bukti yang paling dapat diandalkan dan bahkan menjadi tulang punggung (back-bone) dalam proses peradilan pidana terutama pada pengungkapan perkara/pelaku dalam proses penyidikan. Hal ini diakui oleh beberapa pakar forensik dimana apabila pembuktian di pengadilan tidak ditemukan saksi maka hasil pemeriksaan barang buktimenjadi alat bukti yang utama (andalan). ${ }^{2}$

Latar belakang terjadi pembunuhan di Indonesia sangat bervariasi. Pengertian pembunuhan adalah sebuah perbuatan kriminal yang menyebabkan hilangnya nyawa seseorang, saat ini banyak terjadi pembunuhan di berbagai daerah Indonesia. Hal ini selain dipengaruhi motif atau latar belakang dari sang pelaku,juga merupakan gambaran merosotnya moral bangsa ini. Kemerosotan moral, himpitan ekonomi, ketidaksabaran dan kebencian adalah beberapa faktor yang menyebabkan terjadinya pembunuhan. Begitu mudahnya sesorang menghilangkan nyawa orang lain ini patut diteliti penyebabnya. Kerasnya kehidupan dan rapuhnya pendidikan agama mungkin juga menjadi faktor begitu mudahnya seseorang menghilangkan nyawa orang lain. ${ }^{3}$

Maraknya tindak pidana pembunuhan sangatlah diperlukan peran dan tugas pihakpihak yang berwenang diantaranya Kepolisian, Kejaksaan dan Kehakiman. ${ }^{4}$ Kejahatan merupakan suatu istilah yang tidak asing lagi dalam kehidupan bermasyarakat, pada dasarnya istilah kejahatan itu diberikan kepada suatu jenis perbuatan atau tingkah laku manusia tertentu yang dapat dinilai sebagai perbuatan jahat. Perbuatan atau tingkah laku yang dinilai serta mendapat reaksi yang bersifat tidak disukai oleh masyarakat itu, merupakan suatu tindakan yang tidak dibenarkan untuk muncul di tengahtengah kehidupan masyarakat begitu juga dengan kejahatan pembunuhan.sesuai yang diatur dalam Pasal 338 KUHP yang berbunyi "Barang siapa dengan sengaja menghilangkan nyawa orang lain dipidana karena pembunuhan dengan pidana penjara paling lama 15 tahun.” Maupun dalam Pasal 340 KUHP tentang

\footnotetext{
${ }^{1}$ Edi Setiadi, sistem Peradilan Pidana Terpadu dan sistem Penegakan Hukum pidana Di Indonesia, Gramedia Pustaka Utama, Jakarta, 2017, hlm 32

${ }^{2}$ Soeparmono, Keterangan Ahli dan Visum et Rapertum Dalam Aspek Hukum Acara Pidana, Mandar Maju, Cetakan ke-III, Bandung, 2011, hlm 47

${ }^{3}$ W.A. Gerungan, Psikologisosial, Aditama, Bandung. 2004, hlm.1 56

${ }^{4}$ Adami Chazawi, Kejahatan Terhadap Tubuh Dan Nyawa, Raja Grafindo Persada, Jakarta, 2010, hlm.
} 
pembunuhan berencana yang berbunyi "Barang siapa dengan sengaja dan dengan rencana terlebih dahulu merampas nyawa orang lain, diancam karena pembunuhan berencana, dengan pidana mati atau penjara seumur hidup atau selama waktu tertentu, paling lama dua puluh tahun." Sistem peradilan pidana (criminal justice system) merupakan salah satukegiatan yang dilaksanakan oleh sub system peradilan sebagai lembaga penegakan hukum dalam melaksanakan tugas, fungsi dan perannya dalam penegakan hukum yang dapat menjamin rasa keadilan bagi masyarakat, melindungi kepentingan Negara, demi terciptanya suatu kepastian hukum dan menghargai hak asasi manusia. ${ }^{5}$

Dalam melakukan penyidikan, penyidik memiliki peran yang sangat penting dalam mengidentifikasi seseorang, baik seseorang itu sebagai penjahat ataupun korban untuk menemukan identitas diri seseorang tersebut. Dalam proses penyidikan terdapat satu unit khusus yang menjadi ujung tombak kepolisian untuk mengumpulkan bukti guna membantu proses penyidikan, unit ini disebut unit identifikasi atau INAFIS (Indonesia automatic fingerprint system). Pada tingkat Polres dikenal adanya Unit Identifikasi, begitu juga pada Polresta Padang.

Berdasarkan latar belakang yang dipaparkan di atas, maka permasalahan yang akan dibahas adalah peran unit identifikasi forensik dan optimalisasi dari peran tersebut.

\section{METODE PENELITIAN}

Spesifikasi penelitian adalah deskriptif analitis, dengan metode pendekatan yuridis normative didukung oleh yuridis empiris. Jenis data yang digunakan adalah data sekunder. Data sekunder diperoleh dari studi dokumen dan studi kepustakaan. Data yang diperoleh kemudian dianalisa secara kualitatif.

\section{PEMBAHASAN}

\section{A. Peran Unit Identifikasi Forensik Dalam Penyidikan Tindak Pidana Pembunuhan Pada LP 310/A/VIII/2020/Sektor Dan LP 128-B/V/2020/LUBEG}

Penyelenggaraan identifikasi Kepolisian dimaksudkan untuk kepentingan tindak pidana dan pelayanan identifikasi nontindak pidana bagi masyarakat dan instansi lain dalam rangka pelaksanaan fungsi Kepolisian. Identifikasi secara harfiah adalah berasal dari kata to Identify artinya mengenal kembali. Identity artinya ciri-ciri. Dalam perkembangan identifikasi diartikan sebagai pengenalan kembali terhadap seseorang, benda atau hewan dengan cara mengenali melalui ciri-ciri yang ada pada orang atau hewan dan benda tersebut.

Peran Unit Identifikasi sangat penting dalam mengungkap suatu tindak pidana atau kejahatan. Unit identifikas melakukan pembuktian awal bahwa patut diduga telah terjadi tindak pidana melalui fakta-fakta yang ditemukan di Tempat Kejadian Perkara. Hasil kegiatan Unit Identifikasi merupakan modal dalam pengungkapan tindak pidana. Dalam pengusutan kasus pembunuhan, Pihak Kepolisian selain mencari jejak tersangka juga memfokuskan penyidikan kepada Korban hal ini dengan harapan jika jati diri korban dapat diketahui maka pelaksanaan penyidikan dapat dilakukan dengan lebih

\footnotetext{
${ }^{5}$ Romli Atmasmita, Sistem Peradilan Pidana Kontemporer, Kencana Pranada Media Grup, Jakarta, 2010, hlm. 2
} 
terarah oleh karena pada umumnya ada hubungan antara pelaku dan korbannya sehingga penyidik dapat lebih mudah membuat daftar orang-orang yang dapat dicurigai sebagai pelaku tindak pidana. Daftar sebagaimana tersebut dapat lebih diringkas jika waktu kematian korban dapat diketahui dan alat yang dilakukan untuk melakukan kejahatan oleh pelaku telah ditemukan. Dalam kasus pembunuhan, pencarian sidik jari dalam perkara pembunuhan pada umumnya dilakukan pada objek sebagai berikut :

1. Objek yang dirusak oleh tersangka;

2. Benda-benda yang dipakai oleh tersangka;

3. Harta milik yang ditemukan kembali;

4. Tempat masuknya tersangka;

5. Benda-benda yang dipindahkan atau dipegang oleh tersangka;

6. Tempat keluarnya tersangka.

Menurut pejabat kepolisian Unit Identifikasi Polresta Padang mengatakan bahwa, Ada beberapa aspek yang perlu diperhatikan dalam pola penanganan yang dilakukan oleh pihak kepolisian yang dalam hal ini adalah peranan unit identifikasi dalam mengungkap suatu tindak pidana pembunuhan adalah yang pertama Sidik Jari sebagai Alat Bukti. Seperti pada perkara dengan LP 310/A/VIII/2016/Sektor Padang Selatan. Dimana pada perkara ini ditemukan seorang laki-laki yang terapung di pinggir Sungai Batang harau. Bhabinkamtibmas setempat bersama dengan masyarakat kemudian mengangkat mayat tersebut ke pinggir Sungai dan kondisi korban sudah dalam keadaan meninggal. Pada saat ditemukan mayat tidak menggunakan baju dan memakai celana panjang warna hitam, memakai jam tangan di sebelah kanan. Sekira pukul 08.30 WIB Tim Identifikasi Polresta beserta Piket SPK Polresta Padang sampai di TKP, selanjutnya tim Inafis melakukan identifikasi terhadap mayat. Identifikasi dilakukan terhadap sidik jari korban.

Adapun langkah-langkah penyidikan yang dilakukan oleh penyidik dimulai dari mendatangi tempat kejadian perkara, memeriksa apa yang ada pada tubuh mayat, pemotretan dan pembuatan sketsa, pencarian alat-alat bukti yang tertinggal terutama alatalat fisik seperti bekas sidik jari yang dimungkinkan pada alat-alat tersebut dan pemeriksaan orang-orang yang dianggap dapat memberikan keterangan, pencarian dan pengerjaan serta penangkapan dan penahanan para tersangka sampai dengan penyerahan berkas berita acara kepada penuntut umum/kejaksaan. Apabila diperlukan maka akan dilakukan otopsi terhadap mayat tersebut.

Berdasarkan data tersebut diatas, dalam penanganan pada kasus pembunuhan yang oleh ditangani oleh unit identifikasi, dikatakan bahwa dalam proses penanganannya, ada beberapa tahapan yang dilakukan dalam menangani kasus pembunuhan tersebut, yang diantaranya mendatangi dan memotret tempat kejadian perkara pembunuhan. Kemudian tim identifikasi akan melakukan pengamatan di dalam tempat kejadian perkara pembunuhan. Selanjutnya dilakukan pemotretan dimana pada setiap langkah ditandai menggunakan pola spiral, lingkaran atau zigzag. Tim kemudian Mengambil sample yang diduga terdapat sidik jari pelaku. Membuat berita acara hasil identifikasi yang dilakukan dan diserahkan kepada penyidik yang berwenang. Penjelasan tersebut diatas merupakan suatu proses tindakan yang dilakukan oleh unit identifikasi 
Polresta Padang, dalam melakukan fungsi dan tugasnya. Adakalanya dalam suatu perkara pembunuhan tim identifikasi memerlukan pemeriksaan lebih lanjut oleh dokter forensik.

Dokter adalah seorang tenaga kesehatan untuk menyelesaikan semua masalah kesehatan. Keterkaitan dokter dengan penyelidikan tindak pidana adalah seorang dokter menjadi tenaga ahli dalam melakukan pemeriksaan terhadap korban tindak pidana. Dokter dalam melakukan tugas sehari-hari, suatu waktu dapat diminta bantuannya oleh penegak hukum, maka sangatlah baik bila dokter mengetahui tentang tata laksana penyidikan perkara pidana, mulai dari saat penyidik sampai hakim menjatuhkan keputusan. Mendatangkan seorang dokter yang diperlukan sehubungan dengan perkara tidak termasuk wewenangnya. Dokter boleh dikatakan tidak ada hubungannya kerja dengan penyelidik.

Dari hambatan-hambatan yang ada tersebut tidak mematahkan semangat dari para penyidik untuk tetap melanjutkan penyelidikan terhadap kasus tersebut. Para penyidik menelusuri ulang rangkaian kejadian mulai dari tempat kejadian perkara, orang tua korban, saksi-saksi yang masih ada. Akan tetapi setelah beberapa hari tetap tidak diketemukan suatu petunjuk baru. Untuk itu para penyidik memutuskan untuk memanggil kehadiran tenaga ahli, dalam hal ini adalah dokter forensik untuk melakukan ekshumasi. Ekshumasi adalah suatu tindakan medis yang dilkukan atas Undang-undang dalam rangka pembuktian suatu tindakan pidana dengan menggali kembali jenazah yang sudah dikuburkan dan berdasarkan izin dari keluarga korban. Akhirnya dengan dilakukannya proses tersebut oleh tenaga ahli, kembali penyidik mendapatkan petunjuk baru yang lebih jelas. Jadi peran tenaga ahli dalam proses penyelidikan kasus ini berandil besar dalam penyelesain kasuskasus pidana yang membutuhkan tenaga ahli tersebut.

\section{B. Kendala Peran Unit Identifikasi Forensik Dalam Penyidikan Tindak Pidana Pembunuhan Pada LP 310/A/VIII/2020/Sektor Dan LP 128-B/V/2020/LUBEG}

Menurut Petugas Unit Identifikasi Polresta Padang, mengatakan bahwa, seringkali di dalam melakukan tugas penyidikan, petugas menemui hambatan atau bahkan gagal dalam mengumpulkan bukti dari tempat kejadian perkara. Adapun kendala yang ditemui penyidik dalam kegiatan yang dilakukan oleh unit identifikasi untuk membantu penyidikan yaitu Faktor petugas yang mempunyai peranan yang sangat dominan dalam mengolah tempat kejadian perkara guna mengumpulkan bukti untuk penyidikan selanjutnya. Kemampuan petugas dalam melakukan identifikasi merupakan unsur penting dalam mencari bukti, kemampuan petugas yang kurang menguasai pengetahuan tentang identifikasi akan kesulitan dalam mencari bukti atau bahkan justru merusak jejak pelaku yang seharusnya dapat dijadikan bukti.

Tim Unit Identifikasi Polrestas Padang dalam mengungkap pelaku tindak pidana pembunuhan yang sedang melakukan proses pengolahan pada tempat kejadian terkadang dalam mencari bukti-bukti yang terdapat pada tempat kejadian perkara bisa saja kurang teliti, mengabaikan ataupun menghiraukan sesuatu tandatanda, benda-benda, jejak-jejak dan sebagainya, yang sebenarnya jika dilakukan dengan teliti dan menganggap penting terhadap apa saja atau seluruh yang ada di tempat kejadian perkara akan membuat jelas dan terang tentang telah terjadinya suatu tindak pidana. 
Minimnya Sarana dan Prasarana Guna mendukung proses pengolahan tempat kejadian perkara harus didukung dengan sarana dan prasarana yang lengkap, sehingga akan mempermudah Unit Identifikasi Polresta Padang dalam mengungkap pelaku tindak pidana pembunuhan dalam melakukan penanganan dan pencarian bukti yang ada ditempat kejadian perkara. Namun dalam kenyataannya banyak terjadi kendala dalam hal sarana dan prasarana, misalnya dalam hal sarana agar sampai ketempat kejadian perkara dibutuhkan kendaraan, memang ada disediakan mobil patroli namun jumlahnya minim dan ada yang sudah dalam keadaan rusak sehingga tidak bisa dipakai. Sehingga terkadang harus menggunakan kendaraan pribadi jika ada, sehingga tidak efisien dalam hal waktu, sehingga dengan telah diketahuinya kejadian tindak pidana oleh masyarakat luas maka akan kemungkinan jejakjejak yang ada pada tempat kejadian tersebut telah terkontaminasi dengan jejak masyarakat sebelum dilakukannya penutupan lokasi tersebut dengan garis polisi yang disebabkan keterlambatan polisi yang datang hanya karena ketiadaannya sarana.

Peralatan untuk melakukan identifikasi juga merupakan salah satu faktor terpenting di dalam melakukan identifikasi. Kelengkapan peralatan untuk penyidikan juga sangat menunjang keberhasilan penyidik dalam mengumpulkan bukti, keterbatasan alat juga berpengaruh terhadap keterbatasan bukti yang dikumpulkan. Terlebih apabila penyidik dihadapkan pada tempat kejadian perkara yang sudah lama, disebabkan karena tindak pidana baru diketahui setelah sekian lama.

Kendala selanjutnya adalah Kurangnya kesadaran hukum dan kepedulian masyarakat mengenai tindak pidana dan proses penyidikan di tempat kejadian perkara dalam kasus pidana, dapat mengakibatkan kesulitan bagi penyidik dalam mendapatkan bukti. Antusias masyarakat di sekitar lokasi tempat kejadian perkara bisa menjadi ancaman besar terutama pada keaslian tempat kejadian perkara, hal ini dikarenakan pada umumnya masyarakat ingin menyaksikan apa yang telah terjadi, dan tanpa sepengetahuannya dapat mengakibatkan hilangnya jejak pelaku dan bahkan rusaknya sidik jari latent pelaku karena terhapus atau tertumpuk oleh masyarakat saat menyentuh atau memindahkan barang-barang yang mungkin terpegang oleh pelaku kejahatan dan korban. Kekurangtahuan masyarakat akan pentingnya Penanganan tempat kejadian perkara, masyarakat yang berada disekitar tempat kejadian perkara dengan rasa keingintahuan yang sangat besar terhadap kejadian tersebut secara spontan akan langsung mendatangi tempat kejadian perkara untuk melihat secara langsung kejadian tersebut dan tidak jarang masyarakat memegang ataupun melakukan tindakan-tindakan lain ditempat kejadian perkara, sehingga tanpa disadari oleh masyarakat, dengan adanya keberadaan mereka didekat ataupun disekitar tempat kejadian perkara yang belum dilakukan tindakan pertama ataupun pengolahan tempat kejadian perkara akan merusak jejak-jejak ataupun bukti-bukti lain yang sebenarnya sangat menentukan/penting terhadap kejadian tersebut dan akan terkontaminasi/bercampur dengan jejak masyarakat itu sendiri.

Kendala lain adalah faktor waktu semakin cepatnya suatu peristiwa/tindak pidana diketahui maka akan semakin memudahkan Unit Identifikasi Polresta Padang dalam mengungkap pelaku tindak pidana pembunuhan berencana dan menemukan bukti bukti yang ada pada tempat kejadian perkara sebab kejadian tersebut masih baru terjadi 
sehingga bukti-bukti yang ada pada tempat kejadian perkara masih utuh dan kemungkinan untuk rusak ataupun menghilang dapat dihindari.

Faktor cuaca akan menjadi kendala yang sangat besar terutama jika tindak pidana tersebut terjadi diluar ruangan yang tertutup sehingga secara langsung benda-benda, jejak-jejak ataupun bukti-bukti lain akan berhadapan dengan cuaca. Misalnya dalam melakukan pengolahan tempat kejadian perkara untuk mencari bukti tidak pidana pembunuhan pada tempat kejadian perkara yang berada diluar ruangan/ tempat yang terbuka dan pada saat pengolahannya terjadi hujan. Seperti kasus ditemukannya mayat mengapung di sungai.

Faktor alam sangat memungkinkan untuk terjadinya berubahnya tempat kejadian perkara, keadaan cuaca/iklim, kelembaban, suhu udara, dan perubahan perubahan temperatur di suatu daerah dimana sidik jari latent ditinggalkan, keadaan alam tersebut mengakibatkan berbagai kemungkinan, baik kesulitan dalam melakukan identifikasi atau bahkan hilangnya bukti-bukti yang ada. Faktor alam merupakan penghambat alamiah yang bisa terjadi kapan saja, bisa dikarenakan oleh perubahan cuaca atau memang tindak pidana tersebut terjadi dalam keadaan alam yang kurang baik untuk mendapatkan bukti tindak pidana, misalnya tindak pidana terjadi saat keadaan hujan lebat

\section{Optimalisasi Peran Unit Identifikasi Forensik Pada Satreskrim Polresta Padang Dalam Penyidikan Tindak Pidana Pembunuhan}

Upaya optimalisai yang lain yang dapat dilakukan adalah merumuskan dan melaksanakan evaluasi kegiatan yang terprogram baik itu periode mingguan, triwulan dan tahunan, dengan tujuan untuk meningkatkan kemampuan, keterampilan dan profesionalisme personel unit identifikasi. Polresta Padang juga mengusahakan ruang pustaka yang berisi buku-buku yang mendukung tugas, fungsi dan wewenang unit identifikasi khususnya dan Satreskrim secara umum. Sehingga setiap saat anggota Kepolisian dapat membaca buku-buku tersebut guna meningkatkan kualitas tugasnya sesuai dengan fungsinya masing-masing, terutama personel pada unit identifikasi.

Berkaitan dengan masih adanya anggota pada unit identifikasi yang belum mempunyai sertifikat keahlian tertentu berkaitan dengan tugas unit identifikasi di lapangan maka untuk mengatasi permasalahan tersebut di atas diharapkan adanya kerjasama yang lebih dengan berbagai pihak terkait.

Berkaitan dengan sarana dan prasarana secara fisik dapat diupayakan dengan mengajukan kebutuhan sarana dan prasarana baik secara langsung maupun tidak langsung kepada pihak pimpinan atas yaitu Kapolresta Padang, serta memberikan kepercayaan kepada anggota unit identifikasi untuk terus berkarya, berinovasi, dan berkreasi sesuai dengan aturan dan kemampuannya masing-masing. Sedangkan untuk kelengkapan barang bukti tentang hasil identifikasi lapangan berupa sidik jari dan sample barang bukti lainnya, selalu bekerja sama dengan Puslabfor Polda Sumbar karena selama ini hasil identifikasi yang diakui di pengadilan adalah hasil identifikasi yang dikeluarkan oleh Puslabfor Polri. Upaya upaya yang dilakukan pada dasarnya untuk meningkatkan kompetensi personel. Hal ini penting bahwa kompetensi adalah suatu kemampuan untuk melaksanakan atau melakukan suatu pekerjaan atau tugas yang dilandasi atas keterampilan dan pengetahuan serta didukung oleh sikap kerja yang dituntut oleh 
pekerjaan tersebut. Dengan demikian, kompetensi menunjukan keterampilan atau pengetahuan yang dicirikan oleh profesionalisme dalam suatu bidang tertentu sebagai sesuatu yang terpenting, sebagai unggulan bidang tersebut.

Ilmu yang mempelajari tentang sidik jari adalah Daktiloskopi yang berasal dari dua kata Yunani yaitu Dactilos yang berarti jari jemari/garis garis jari dan Scopein berarti mengamati/meneliti. Penyelenggaraan Daktiloskopi adalah kegiatan mencari, menemukan, mengambil, merekam, mengamati, mempelajari, mengembangkan, merumuskan, mendokumentasikan, mencari kembali dokumen, dan membuat keterangan sidik jari seseorang. Kegiatan pelaksanaan dari hal tersebut diatas dilakukan oleh orang yang ahli dalam teknis identifikasi sidik jari atau yang biasa dikenal dengan petugas unit identifikasi sidik jari. Sidik jari sendiri merupakan hasil reproduksi tapak jari, baik yang sengaja diambil atau dicapkan dengan tinta khusus sidik jari maupun bekas yang ditinggalkan pada benda karena pernah tersentuh dengan kulit telapak tangan maupun kaki. dalam sidik jari untuk keperluan pendataan dikenal dengan istilah Data Sidik yaitu rekaman jari tangan atau telapak kaki yang terdiri atas kumpulan alur garis-garis halus dengan pola tertentu.

\section{PENUTUP}

Optimalisasi Peran Unit Identifikasi Forensik Pada Satreskrim Polresta Padang Dalam Penyidikan Tindak Pidana Pembunuhan adalah mengusulkan secara berjenjang untuk mengikutsertakan personel unit identifikasi pada pendidikan khusus bidang identifikasi tindak pidana. bagian kelengkapan sarana dan prasarana diupayakan untuk membuat piranti lunak berupa program komputer perihal Penyidikan maupun Penyelidikan Kriminal dan Pengamanan Fisik yang memuat serangkaian kegiatan penyelidikan guna pencegahan, mencari serta menemukan suatu peristiwa yang diduga pelaku, saksi dan barang bukti tindak pidana yang dilanggar agar dapat dilakukan penyidikan menurut cara yang diatur oleh undang-undang, khususnya untuk tindak pidana pembunuhan. Pemberian penghargaan terhadap personel yang memiliki kreativitas, inovasi, dan motivasi yang tinggi dengan cara memberikan hadiah berupa barang atau piagam dan mendapatkan prioritas dalam pendidikan, perumahan dinas dan sebagainya. Ketika personel yang bersangkutan mempunyai prestasi dalam kinerjanya mengungkap suatu tindak pidana pembunuhan.

\section{REFERENSI}

Edi Setiadi, sistem Peradilan Pidana Terpadu dan sistem Penegakan Hukum pidana Di Indonesia, Gramedia Pustaka Utama, Jakarta, 2017

Soeparmono, Keterangan Ahli dan Visum et Rapertum Dalam Aspek Hukum Acara Pidana, Mandar Maju, Cetakan ke-III, Bandung, 2011.

W.A. Gerungan, Psikologi sosial, Aditama, Bandung. 2004

Adami Chazawi, Kejahatan Terhadap Tubuh Dan Nyawa, Raja Grafindo Persada, Jakarta, 2010

Romli Atmasmita, Sistem Peradilan Pidana Kontemporer, Kencana Pranada Media Grup, Jakarta, 2010 